\section{OP -453}

下部尿路症状およびQOL に対するク エン酸塩製剤の有効性の検討一 $\mathrm{pH} メ ー$ ターによる検討

\section{京都市立病院泌尿器科}

上田 朋宏, 吉田 徹, 田上 英毅, 岡村 基弘, 熱田 雄

【目的】我々は頻尿患者を対象としたクエン酸塩製剤の有 効性を検討する臨床研究を実施した（50 例、2006 年 5 月 〜 2008 年 3 月)。その結果、症状と尿 $\mathrm{pH}$ の関連性や酸性 尿の改善が排尿回数、不快感・痛みの回数の減少、QOL スコアの改善に関連することを 1 昨年と昨年の本総会で報 告した。一方、毎排尿時スポット尿の $\mathrm{pH}$ は尿 $\mathrm{pH}$ 試験紙 の測定下限である 5.2 の記録も多く、正確な尿 $\mathrm{pH}$ の測定 が必要と思われた。また、先の研究で痛みのある患者に特 に有効であったことから、治療対象を下部尿路の不快感 ·

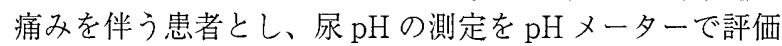
した。【対象】下部尿路症状があり、酸性尿と下部尿路の 不快感・痛みのある患者。【方法】1）観察期に排尿回数、 排尿量、不快感・痛み、尿 $\mathrm{pH} 、 \mathrm{QOL}$ を記録する。尿 $\mathrm{pH}$

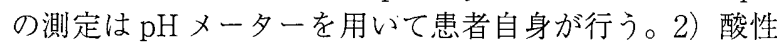
尿と不快感・痛みが確認できた患者はクエン酸塩製剂で 4 週間治療（必要な場合増量）し、症状、尿 $\mathrm{pH}$ 等を観察期 と同様に記録する。【結果】本抄録作成時の終了例 3 例で は、 $\mathrm{pH} 5.2$ 未満のスポット尿の分布が観湘され、尿 $\mathrm{pH}$ 正確に測定されていることが分かった。また、不快感、痛 みのスコアに有意な改善が認められた。【結論】臨床研究 は2009年 1 月より組み入れ中だが、強度の酸性尿が下部 尿路症状を修飾している患者が確実にいることが明らかと なった。

\section{OP-454}

女性排尿困難症患者 25 例への経尿道的 膀胱頚部切開術 TUIBN:Trans Urethral Incision of Bladder Neck の適用

\section{米沢市立病院泌尿器科}

高岩 正至

【目的】女性排尿困難に薬物治療が困難な場合に、やむな く間欠的導尿（自己・介助）またはカテーテル留置が選択 される。しかし患者・家族は自排尿が可能になること（ト イレ排尿・オムツ排尿）を希望されることも多い。尿排出 症状を改善するための手術法を検討した。【方法】尿閉・ 水腎症・VUR を伴う排尿困難症状が薬物療法で治癒され ない症例で、間欠的導尿 (自己・介助) や尿道カテーテル 留置状態を好まず、自排尿状態（トイレ排尿・オムツ排尿） を希望された患者を対象とした。TURの電気メス切開ルー プにて 2 時、 6 時、10 時方向の 3 箇所、膀胱䅡部を中心に 前後方向に $20 \mathrm{~mm}$ 程度ずつ $5 \mathrm{~mm}$ 前後の哚さで切開を加え た。失禁にバイアスをかける場合には 2 時と 10 時の切開 を尿道の中央位置を越えて外尿道口まで 3 時と 9 時に方向 修正しながら延長切開した。若年・ADL が高いほど術後 尿失禁にならないように（導尿併用の可能性があっても）、 高齢・ADL が低いほど術後排尿困難にならないように（才 ムツ排尿のみになっても) 切開範囲を設定した。【成績】 尿失禁も残尿もない excellent 群が $60 \%$ 、術前のリスクを 話したとおりの尿失禁または間歇導尿を必要とした good 群が40\%であった。【結論】方法は患者・家族の needs が 高く、普及すべき治療法と考える。

\section{OP-455原三信病院における TOT手術の成績と 患者満足度}

\section{原三信病院泌尿器科}

相島 真奈美, 田中 祥子, 武井 実根雄, 山口 秋人 【目的】腹圧性尿失禁（SUI）に対する TOT 手術症例につ いてその臨床成績と患者満足度について検討する。【対象 と方法】 2005 年 4 月より 2008 年 8 月に当院で TOT 手術 を受けた 116 名【結果】平均年齢 61 歳 (40-80 歳)、子宮 摘出術後が 23 名（19.8\%）あった。術前パッドテストは $1-440 \mathrm{~g}$ (中央值 25g)、術前 UD で ISD と診断されたもの が 30 例 (25.9\%) あった。TOT単独施行症例の手術時間 は 15-48 分 (平均 24 分)、出血量は 0-200g (平均 18.3g) であった。15例にTVM-A を、9 例に膀胱水圧拡張術を併 用した。手術合併症は剥離時の腔壁裂傷のみであった。術 後 SUI が消失または著明改善が 105 例 (90.5\%)、残存を 11 (9.5\%) に認めた。失禁残存はほとんどが ISD 症例で、 追加治療としてコラーゲン注入を選択する症例が多かっ た。De novo urgency は 5 例 (4.3\%) に認められ、排尿困 難のため自己導尿を要した症例は 7 例で、1 例は半年後に テープ切断を要した。アンケート回収は 85 名 (73.3\%) で、 大変満足、満足と答えたのは $80.1 \%$ であった。不満と答え た原因としては、失禁の改善度（切迫性尿失禁も含む）、 排尿困難、頻尿の順であった。【結論】TOT 手術は有効で 安全な治療法と考えられるが、患者満足度は術後の排尿困 難や切迫性尿失禁の残存、de novo urgencyの出現などに 左右されるため、術前のより詳細な説明と出現時の対応が 大切だと考えられた。

\section{OP-456 TOT 手術の 5 年成績}

\section{昭和大学横浜市北部病院 ${ }^{1)}$, 昭和大学藤が丘病院 ${ }^{2)}$, 鶴巻 温泉病院}

衛藤 志保 ${ }^{1)}$, 島田 誠 ${ }^{2}$, 井上 克己 ${ }^{1)}$, 佐々木 春明 ${ }^{2}$, 椎木 一彦3), 青木 慶一郎 ${ }^{2}$, 奥村 太輔 ${ }^{12}$, 永田 将一1), 小川 雄一郎 ${ }^{11}$, 松原 英司 ${ }^{1)}$, 前田 智子 ${ }^{1)}$

腹圧性尿失禁（SUI）は女性の QOL を著しく障害する疾: 患のひとつである。

数年前まで腹圧性尿失禁に対する手術は、TVT（tensionfree vaginal tape) 手術が主流となっていた。それに対 し、2001年フランスの Delormeらにより TOT（trans obturator tape）手術が開始された。TOT 手術は尿道下か ら閉鎖孔へテープを通す方法で、腹直筋や腹腔内への穿刺 の可能性がなく大量出血や腸管穿孔などの重篤な合併症が 少ないと考えられている。また、TVT 手術と同様の良好 な成績が報告されており、TOT手術を施行する施設が嬶 加している。

当院では 2004 年 7 月から 2009 年 8 月までに 183 件の TOT 手術を施行した。合併症としては術中大量出血 （500ml 以上）を 2 例 $(1.1 \%) 、$ 尿道損傷を 1 例 $(0.5 \%) 、$ 術後残尿増加を 3 例 $(1.6 \%)$ 、術後 2 年で起こったテープ の膀胱内迷入を 1 例 $(0.5 \%)$ に認めたが、いずれも確率 は低く、患者の術後 QOL は著しく改善した。この 183 例 のうち手術から 5 年経過した 28 例について、術後の QOI 評価に重点をおいて後方視的に検討したので報告する。 